\title{
Effect of Zinc Oxide Nanoparticles on Nitrous Oxide Emissions in Agricultural Soil
}

\author{
Ziyi Feng ${ }^{1}$, Yongxiang Yu ${ }^{1}$, Huaiying Yao ${ }^{1,2,3}$ and Chaorong Ge ${ }^{1, *}$ \\ 1 Research Center for Environmental Ecology and Engineering, School of Environmental Ecology and \\ Biological Engineering, Wuhan Institute of Technology, 206 Guanggu 1st Road, Wuhan 430205, China; \\ ziyifeng7@foxmail.com (Z.F.); yxyu@iue.ac.cn (Y.Y.); hyyao@iue.ac.cn (H.Y.) \\ 2 Key Laboratory of Urban Environment and Health, Institute of Urban Environment, \\ Chinese Academy of Sciences, 1799 Jimei Road, Xiamen 361021, China \\ 3 Zhejiang Key Laboratory of Urban Environmental Processes and Pollution Control, Ningbo Urban \\ Environment Observation and Research Station, Chinese Academy of Sciences, 88 Zhongke Road, \\ Ningbo 315800, China \\ * Correspondence: chaorongge@wit.edu.cn
}

check for updates

Citation: Feng, Z.; Yu, Y.; Yao, H.; Ge, C. Effect of Zinc Oxide Nanoparticles on Nitrous Oxide Emissions in Agricultural Soil. Agriculture 2021, 11, 730. https://doi.org/10.3390/ agriculture 11080730

Academic Editors: Laura Zavattaro and José Alfonso Gómez

Received: 26 May 2021

Accepted: 29 July 2021

Published: 31 July 2021

Publisher's Note: MDPI stays neutral with regard to jurisdictional claims in published maps and institutional affiliations.

Copyright: (c) 2021 by the authors. Licensee MDPI, Basel, Switzerland. This article is an open access article distributed under the terms and conditions of the Creative Commons Attribution (CC BY) license (https:/ / creativecommons.org/licenses/by/ $4.0 /)$.
Abstract: Zinc oxide nanoparticles ( $\mathrm{ZnO} \mathrm{NPs}$ ) are widely used and exposed to the soil environment, but their effect on soil nitrous oxide $\left(\mathrm{N}_{2} \mathrm{O}\right)$ emissions remains unclear. In this study, a microcosm experiment was conducted to explore the effects of different ZnO NPs concentrations (0, 100, 500, and $1000 \mathrm{mg} \mathrm{kg}^{-1}$ ) on $\mathrm{N}_{2} \mathrm{O}$ emissions and associated functional genes related to $\mathrm{N}_{2} \mathrm{O}$ amendment with carbon $(\mathrm{C})$ or nitrogen $(\mathrm{N})$ substrates. Partial least squares path modeling (PLS-PM) was used to explore possible pathways controlling $\mathrm{N}_{2} \mathrm{O}$ emissions induced by $\mathrm{ZnO}$ NPs. In the treatment without $\mathrm{C}$ or $\mathrm{N}$ substrates, 100 and $500 \mathrm{mg} \mathrm{kg}^{-1} \mathrm{ZnO}$ NPs did not affect $\mathrm{N}_{2} \mathrm{O}$ production, but $1000 \mathrm{mg} \mathrm{kg}^{-1} \mathrm{ZnO} \mathrm{NPs}$ stimulated $\mathrm{N}_{2} \mathrm{O}$ production. Interestingly, compared with the soils without $\mathrm{ZnO} N P s$, the total $\mathrm{N}_{2} \mathrm{O}$ emissions in the presence of different $\mathrm{ZnO}$ NPs concentrations increased by 2.36-4.85-, 1.51-1.62-, and 6.28-8.35-fold following C, $\mathrm{N}$ and both $\mathrm{C} \& \mathrm{~N}$ substrate amendments, respectively. Moreover, $\mathrm{ZnO}$ NPs increased the functional genes of ammonia-oxidizing bacteria (AOB $a m o A$ ) and nitrite reductase (nirS) and led to the exhaustion of nitrate but reduced the gene copies of ammonia-oxidizing archaea (AOA $a m o A$ ). In addition, the redundancy analysis results showed that the $\mathrm{AOB}$ amoA and nirS genes were positively correlated with total $\mathrm{N}_{2} \mathrm{O}$ emissions, and the PLS-PM results showed that $\mathrm{ZnO}$ NPs indirectly affected $\mathrm{N}_{2} \mathrm{O}$ emissions by influencing soil nitrate content, nitrifiers and denitrifiers. Overall, our results showed that $\mathrm{ZnO} N \mathrm{NP}$ increase $\mathrm{N}_{2} \mathrm{O}$ emissions by increasing nitrification ( $\mathrm{AOB}$ amoA) and denitrification (nirS), and we highlight that the exposure of $\mathrm{ZnO} N \mathrm{NP}$ in agricultural fields probably results in a high risk of $\mathrm{N}_{2} \mathrm{O}$ emissions when coupled with $\mathrm{C}$ and $\mathrm{N}$ substrate amendments, contributing to global climate warming.

Keywords: nanomaterials; nitrification; denitrification; nitrous oxide; soil

\section{Introduction}

In the past few decades, engineered nanoparticles (NPs) have been widely used in industrial, agricultural, and consumer production due to their unique properties (such as antibacterial properties) [1,2]. Meanwhile, most consumed NPs are exposed to the soil environment through the application of wastes and sewage sludge, which causes potential risks for microorganisms due to their toxic effects [3,4]. The presence of NPs in the soil environment affects the activities of nitrifiers and denitrifiers [5-7], which probably influences the release of nitrous oxide $\left(\mathrm{N}_{2} \mathrm{O}\right)$ from the soil to the atmosphere and contributes to global warming and ozone destruction. However, recent publications have reported that the effect of NPs on soil $\mathrm{N}_{2} \mathrm{O}$ emissions depends on their types [8-11]. For example, copper oxide $(\mathrm{CuO})$ [8], silver sulfide $\left(\mathrm{Ag}_{2} \mathrm{~S}\right)$ [9], and high-dose lithium oxide $\left(\mathrm{Li}_{2} \mathrm{O}\right)$ [10] and iron oxide $\left(\mathrm{Fe}_{2} \mathrm{O}_{3}\right)$ [11] NPs could reduce, increase, and not affect soil $\mathrm{N}_{2} \mathrm{O}$ emissions, respectively. 
Zinc oxide $(\mathrm{ZnO}) \mathrm{NPs}$ are the third most used type of nanomaterial [4] and can potentially influence $\mathrm{N}_{2} \mathrm{O}$ production through at least two distinct mechanisms. First, the toxic action of $\mathrm{ZnO}$ NPs or the dissolution of $\mathrm{Zn}^{2+}$ can decrease soil microbial activity related to nitrogen $(\mathrm{N})$ cycling [12-15] and $\mathrm{N}$ mineralization efficiency [14], which then indirectly reduces $\mathrm{N}_{2} \mathrm{O}$ emissions. Second, $\mathrm{ZnO}$ NPs inhibited glucose metabolism enzymes and then reduced the electrons and power for denitrifiers to produce $\mathrm{N}_{2} \mathrm{O}$ [16-18]. In a mineral medium, Zheng et al. [16] found that $\mathrm{ZnO}$ NPs largely inhibited the expression of the nos $Z$ gene related to $\mathrm{N}_{2} \mathrm{O}$ reductase in the denitrification pathway and then increased $\mathrm{N}_{2} \mathrm{O}$ emissions. In a synthetic wastewater system, Ye et al. [18] observed that ZnO NPs reduce $\mathrm{N}_{2} \mathrm{O}$ emissions by enhancing $\mathrm{N}_{2} \mathrm{O}$ reduction. In the soil environment, few studies have focused on the impact of $\mathrm{ZnO}$ NPs on $\mathrm{N}_{2} \mathrm{O}$ emissions. Durenkamp et al. [19] observed that combining $\mathrm{ZnO}$ and $\mathrm{Ag}$ NPs has a minimal impact on $\mathrm{N}_{2} \mathrm{O}$ emissions in soil/sewage sludge mixtures. Rashid et al. [14] found that $\mathrm{ZnO}$ NPs reduced the nitrogen mineralization of leaf litter in sandy soil and then probably reduced the release of $\mathrm{N}_{2} \mathrm{O}$.

In agricultural fields, the input of additional carbon (C) and $\mathrm{N}$ substrates from management practices (such as the application of manure or crop residue) [20-23] has the potential to enlarge $\mathrm{N}_{2} \mathrm{O}$ emissions, which probably changes the impact of NPs on $\mathrm{N}_{2} \mathrm{O}$ production. However, amendment with a $\mathrm{C}$ substrate temporarily creates an anaerobic environment, which further limits the last step of denitrification in soils polluted with $\mathrm{ZnO}$ NPs $[24,25]$ and probably results in a high risk of $\mathrm{N}_{2} \mathrm{O}$. In addition, the amendment of $\mathrm{C}$ could partly supply electrons and power for denitrifiers and likely offset the negative effect of $\mathrm{ZnO}$ NPs on soil nitrifiers and denitrifiers [23]. Meanwhile, the amendment of N fertilizer would increase the nos Z gene, which probably mediates the effect of ZnO NPs on $\mathrm{N}_{2} \mathrm{O}$ reduction [26]. In this study, microcosm experiments were conducted to explore the effect of $\mathrm{ZnO}$ NPs on $\mathrm{N}_{2} \mathrm{O}$ emissions and functional genes related to nitrification and denitrification. We hypothesize that: (1) the incorporation of ZnO NPs into soil inhibits the release of $\mathrm{N}_{2} \mathrm{O}$ from soil in the absence of $\mathrm{C}$ or $\mathrm{N}$ substrates and (2) the exposure of $\mathrm{ZnO}$ NPs would increase $\mathrm{N}_{2} \mathrm{O}$ emissions after $\mathrm{C}$ and $\mathrm{N}$ substrate amendments.

\section{Materials and Methods}

\subsection{Materials and Experimental Design}

Soil samples were collected from farmland without known nanomaterial pollution in the suburbs of Wuhan, China $\left(114^{\circ} 26^{\prime} \mathrm{N}, 30^{\circ} 19^{\prime} \mathrm{E}, 25.89 \mathrm{~m}\right.$ altitude). Soils in the $0-20 \mathrm{~cm}$ layer were sampled at three random sites and then mixed. The sampled soils were passed through a 2-mm sieve and then stored at $4{ }^{\circ} \mathrm{C}$. The soil organic carbon, total nitrogen, $\mathrm{pH}$, and bulk density were $12.4 \mathrm{~g} \mathrm{~kg}^{-1}, 1.4 \mathrm{~g} \mathrm{~kg}^{-1}, 6.8$ and $1.26 \mathrm{~g} \mathrm{~cm}^{-3}$, respectively.

Four $\mathrm{ZnO}$ NPs concentrations and four substrate amendments were conducted in this experiment. Four ZnO NPs levels were 0, 100, 500, and $1000 \mathrm{mg} \mathrm{kg}^{-1}$ soil, which was based on the nominal range of $\mathrm{ZnO}$ NPs concentrations (100-6400 $\left.\mathrm{mg} \mathrm{kg}^{-1}\right)$ in soil [27]. The four amendments included a control (CT), carbon as glucose (C), nitrogen as ammonium (N), and glucose plus ammonium (C AND N). Each treatment included 3 replicates. Deionized water was added to all the soils to achieve $60 \%$ water holding capacity, and the soils were then incubated at $25^{\circ} \mathrm{C}$. ZnO NPs (purity $>99 \%$ and particle size $<100 \mathrm{~nm}$ ) were purchased from Aladdin (Shanghai, China). ZnO NPs (0, 1.5, 7.5, and $15 \mathrm{mg}$ ) were incorporated into $15 \mathrm{~g}$ of air-dried equivalent soil to achieve $0,100,500$, and $1000 \mathrm{mg} \mathrm{kg}^{-1}$ concentrations and then added to $120-\mathrm{mL}$ brown serum bottles. Additionally, $600 \mathrm{mg} \mathrm{C}$ glucose per $1 \mathrm{~kg}$ air-dried soil was added as the $C$ substrate; the selected quantity equaled $100 \%$ of the microbial biomass $C$ of this sampled soil, as suggested by Tian et al. [28]. Nitrogen was added as ammonium sulfate at $56.4 \mathrm{mg} \mathrm{N} \mathrm{kg}^{-1}$ (equal to $140 \mathrm{~kg} \mathrm{~N} \mathrm{ha}^{-1}$ ) based on the application amount of nitrogen fertilizer according to local farmers' practices.

\section{2. $\mathrm{N}_{2} \mathrm{O}$ Emission Measurements}

Before $\mathrm{N}_{2} \mathrm{O}$ measurement, all bottles were opened and placed in a fuming cupboard for $5 \mathrm{~min}$, which was a sufficient duration for the $\mathrm{N}_{2} \mathrm{O}$ in the bottle to adjust to the 
background value in the atmosphere (Figure S1); afterwards, the bottles were sealed with silicone plugs and incubated for 1 day to allow $\mathrm{N}_{2} \mathrm{O}$ to accumulate in the bottle. Meanwhile, four empty bottles were used to measure the initial $\mathrm{N}_{2} \mathrm{O}$ concentrations. On days $1,2,3,5$, and $8,50 \mu \mathrm{L}$ of sampled gas in the headspace was collected, and the $\mathrm{N}_{2} \mathrm{O}$ concentration was analyzed by using a gas chromatography instrument (Agilent 7890B, Agilent, Palo Alto, CA, USA) equipped with an electron capture detector, which attained $\pm 0.1 \%$ precision of the measured $\mathrm{N}_{2} \mathrm{O}$. The sampling frequency decreased with incubation days because the peak $\mathrm{N}_{2} \mathrm{O}$ emissions occurred in the early period, and 8 days was sufficient for $\mathrm{N}_{2} \mathrm{O}$ emissions to decrease to a stable level based on our preliminary experiment. The cumulative $\mathrm{N}_{2} \mathrm{O}$ emissions under different treatments were calculated by linear interpolation between daily emissions and the corresponding time [25].

\subsection{Soil $\mathrm{DOC}, \mathrm{NH}_{4}{ }^{+}$and $\mathrm{NO}_{3}{ }^{-}$Measurements}

At the end of the experiment, all soils were destructively sampled and divided into two parts. Fresh soil (first portion) was used to determine soil chemical properties. Briefly, $3 \mathrm{~g}$ soil was mixed with $2 \mathrm{M} \mathrm{KCl}(15 \mathrm{~mL})$ and shaken for $60 \mathrm{~min}$. Afterwards, the mixture was filtered with a qualitative filter, and then the ammonium $\left(\mathrm{NH}_{4}{ }^{+}\right)$and nitrate $\left(\mathrm{NO}_{3}{ }^{-}\right)$ concentrations were measured using a continuous flow analyzer (Skalar SAN ${ }^{++}$System, Skalar Analytical B.V., Breda, The Netherlands). Another $3 \mathrm{~g}$ of fresh soil was added to $15 \mathrm{~mL}$ of $\mathrm{K}_{2} \mathrm{SO}_{4}$, shaken for $1 \mathrm{~h}$, and filtered with a quantitative filter. These filtered solutions were used to detect dissolved organic carbon (DOC) using a total organic carbon analyzer (Multi-N/C 2100S; Analytik Jena, Jena, Germany).

\subsection{DNA Extraction and $q P C R$ Analysis}

Another part of the soil was freeze-dried at $-80^{\circ} \mathrm{C}$ for 2 days, and then $0.5 \mathrm{~g}$ of soil was used to extract DNA using the FastDNA ${ }^{\mathrm{TM}}$ Spin Kit for Soil (MP Biomedicals, Santa Ana, CA, USA) according to the instruction manual. DNA quantification and quality assessment were carried out using a NanoDrop 2000 Spectrophotometer (Thermo Scientific ${ }^{\circledR}$, Wilmington, DE, USA). The extracted DNA was used to determine the abundances of nitrification (ammonia-oxidizing archaea (AOA amoA) and ammonia-oxidizing bacteria (AOB amoA) and denitrification functional genes (nirK/nirS- and nosZ-encoded nitrite and nitrous oxide reductases, respectively) by the qPCR method using a LightCycler ${ }^{\circledR}$ 480 II (Roche Diagnostics, Basel, Switzerland) [20]. The $20 \mu \mathrm{L}$ reaction mixture for qPCR contained $2.0 \mu \mathrm{L}$ template DNA, $0.5 \mu \mathrm{L}$ of each primer, $10 \mu \mathrm{L}$ GoTaq ${ }^{\circledR} \mathrm{qPCR}$ Master Mix $2 \times$ (Promega, Madison, WI, USA) and $7 \mu \mathrm{L}$ nuclease-free water (Promega, Madison, WI, USA). The primers and thermal cycling conditions of these genes are listed in Table S1.

\subsection{Statistical Analysis}

The differences in cumulative $\mathrm{N}_{2} \mathrm{O}$ emissions, soil chemical properties (DOC, $\mathrm{NH}_{4}{ }^{+}$, and $\mathrm{NO}_{3}{ }^{-}$), and functional genes related to $\mathrm{N}_{2} \mathrm{O}$ (AOA and $\mathrm{AOB}$ amoA, nirK, nirS and nosZ) among the four $\mathrm{ZnO}$ NPs levels were tested by one-way analysis of variance (ANOVA) using the least significant difference (LSD) test at the level of $p<0.05$. All statistical analyses were conducted using SPSS 20.0 (SPSS Inc., Chicago, IL, USA). Redundancy analysis (RDA) was applied with CANOCO 4.5 (Microcomputer Power, Ithaca, NY, USA) to analyze the correlations of $\mathrm{N}_{2} \mathrm{O}$ emissions and environmental variables (DOC, $\mathrm{NH}_{4}{ }^{+}$and $\mathrm{NO}_{3}{ }^{-}$) with functional genes related to nitrification (AOA and $\mathrm{AOB} a m o A)$ and denitrification (nirK, nirS, and nosZ). Partial least squares path modeling (PLS-PM) was used to explore possible pathways controlling $\mathrm{N}_{2} \mathrm{O}$ emissions induced by $\mathrm{ZnO}$ NPs addition.

\section{Results}

\subsection{Effect of $\mathrm{N}_{2} \mathrm{O}$ Emission}

In the $\mathrm{CT}$ treatment, low daily $\mathrm{N}_{2} \mathrm{O}$ emissions $\left(<1.48 \mu \mathrm{g} \mathrm{N} \mathrm{kg}{ }^{-1}\right.$ day $\left.^{-1}\right)$ were detected at $\mathrm{ZnO}$ NPs concentrations below $500 \mathrm{mg} \mathrm{kg}^{-1}$, but these values ranged from 1.95 to $5.54 \mu \mathrm{g} \mathrm{N} \mathrm{kg}^{-1}$ day $^{-1}$ at the $1000 \mathrm{mg} \mathrm{kg}^{-1} \mathrm{ZnO}$ NPs level (Figure 1a). The presence of 
$\mathrm{ZnO} N$ Ps accelerated the production of $\mathrm{N}_{2} \mathrm{O}$ in the $\mathrm{C}$ treatment, and the peaks of $\mathrm{N}_{2} \mathrm{O}$ emission were 43.67, 106.24, 221.59 and $199.61 \mu \mathrm{g} \mathrm{N} \mathrm{kg}^{-1} \mathrm{day}^{-1}$ for $0,100,500$, and $1000 \mathrm{mg} \mathrm{kg}^{-1} \mathrm{ZnO}$ NPs concentrations, respectively (Figure 1b). However, incorporating $\mathrm{ZnO} N$ Ps into soils slightly stimulated the effect of $\mathrm{N}$ addition on $\mathrm{N}_{2} \mathrm{O}$ emissions, resulting in daily emissions of $1.02-4.14 \mu \mathrm{g} \mathrm{N} \mathrm{kg}{ }^{-1}$ day $^{-1}$ in the treatment without $\mathrm{ZnO}$ NPs and 2.36-6.35 $\mu \mathrm{g} \mathrm{N} \mathrm{kg}^{-1} \mathrm{day}^{-1}$ in the soils under different ZnO NPs levels (Figure 1c). $\mathrm{ZnO}$ NPs amendment considerably stimulated $\mathrm{N}_{2} \mathrm{O}$ emissions following both $\mathrm{C}$ and $\mathrm{N}$ addition; the peaks of $\mathrm{N}_{2} \mathrm{O}$ emissions ranged from 459.39 to $680.41 \mu \mathrm{g} \mathrm{N} \mathrm{kg}^{-1} \mathrm{day}^{-1}$ in the treatment with $\mathrm{ZnO}$ NPs, while this variable was $77.07 \mu \mathrm{g} \mathrm{N} \mathrm{kg}{ }^{-1}$ day $^{-1}$ without $\mathrm{ZnO}$ NPs (Figure 1d).
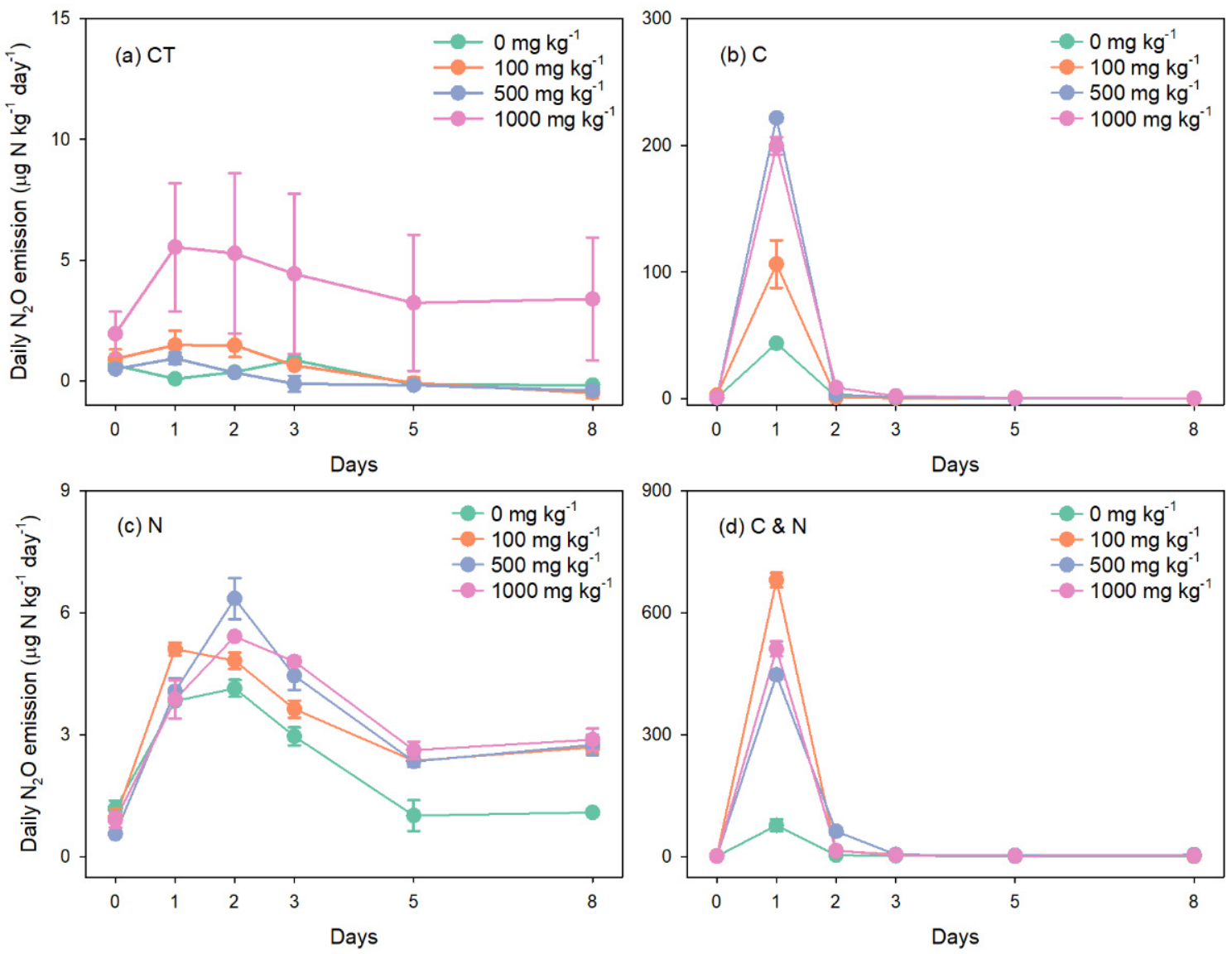

Figure 1. $\mathrm{N}_{2} \mathrm{O}$ emissions in the treatments with no addition (a), $\mathrm{C}$ addition (b), $\mathrm{N}$ addition (c), and $\mathrm{C}$ and $\mathrm{N}$ addition (d) at different $\mathrm{ZnO}$ NPs concentrations (0, 100, 500 and $1000 \mathrm{mg} \mathrm{kg}^{-1}$ ). Error bars represent the standard error of the mean $(n=3)$.

In the absence of $\mathrm{C}$ or $\mathrm{N}$ substrates, there were no significant differences in cumulative $\mathrm{N}_{2} \mathrm{O}$ emissions among the four $\mathrm{ZnO}$ NPs concentrations, although these values were greater at the $1000 \mathrm{mg} \mathrm{kg}^{-1}$ level $\left(34.27 \mu \mathrm{g} \mathrm{N} \mathrm{kg}^{-1}\right)$ than at low concentrations (Figure 2). The presence of $\mathrm{ZnO}$ NPs significantly increased $\mathrm{N}_{2} \mathrm{O}$ emissions after $\mathrm{C}$ or $\mathrm{N}$ addition (Figure 2), and we found that $\mathrm{C}, \mathrm{N}$ and their interactions significantly $(p<0.01)$ affected total $\mathrm{N}_{2} \mathrm{O}$ emissions (Table 1). Compared with the soils without $\mathrm{ZnO} N P s$, the total $\mathrm{N}_{2} \mathrm{O}$ emissions in the presence of different $\mathrm{ZnO}$ NPs concentrations increased by 2.36-4.57, 1.51-1.62, and 6.24-8.30 times in the soil amendment with C, N, and C AND N substrates, respectively. 


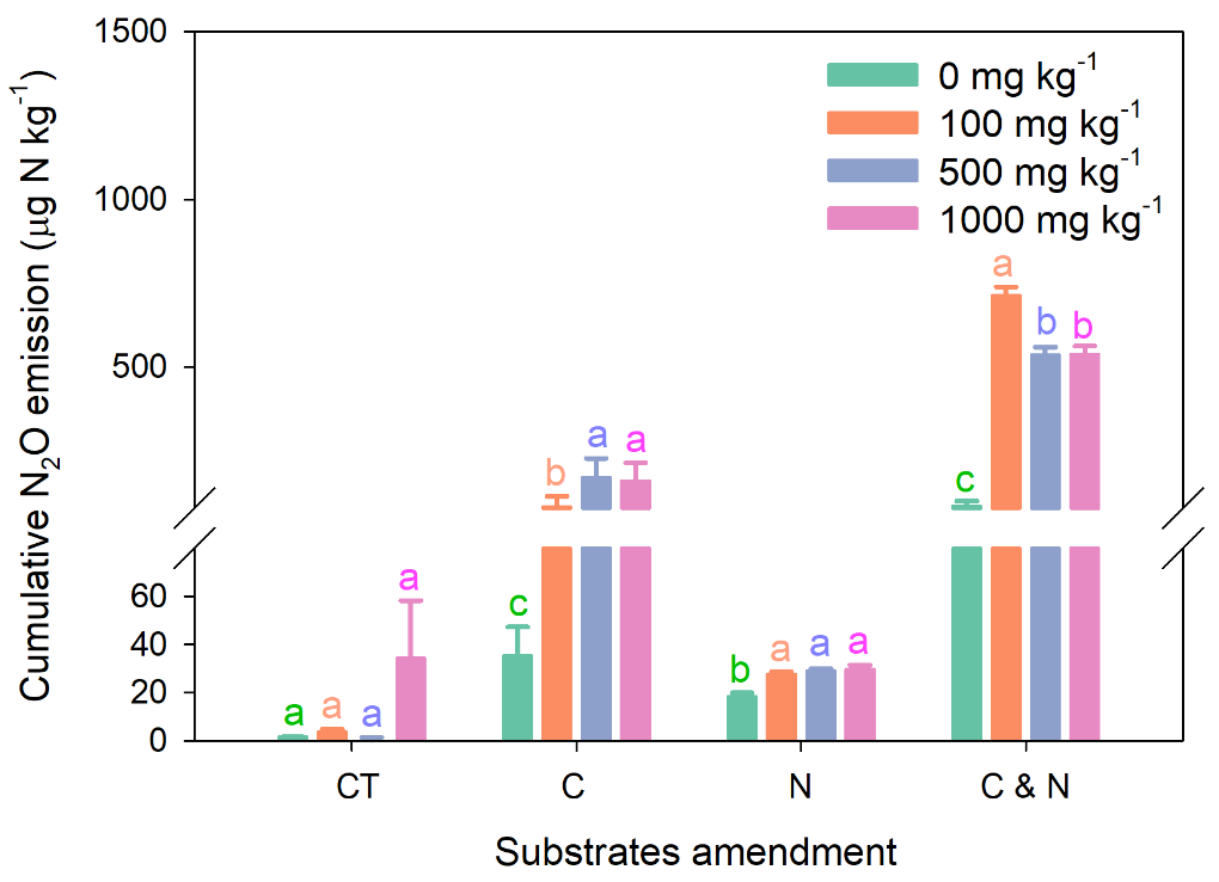

Figure 2. Cumulative $\mathrm{N}_{2} \mathrm{O}$ emissions in the treatments with no addition, $\mathrm{C}$ addition, $\mathrm{N}$ addition and $\mathrm{C}$ and $\mathrm{N}$ addition at different $\mathrm{ZnO}$ NPs concentrations $\left(0,100,500\right.$ and $\left.1000 \mathrm{mg} \mathrm{kg}^{-1}\right)$. Error bars represent the standard error of the mean $(n=3)$.

Table 1. Main and interactive effects of $\mathrm{C}$ and $\mathrm{N}$ substrate amendments on soil $\mathrm{N}_{2} \mathrm{O}$ emission, DOC, $\mathrm{NH}_{4}{ }^{+}$and $\mathrm{NO}_{3}{ }^{-}$contents and functional genes (AOA and $\mathrm{AOB}$ amoA, nirK, nirS and nosZ) related to $\mathrm{N}_{2} \mathrm{O}$ in the presence of $\mathrm{ZnO}$ NPs.

\begin{tabular}{cccccccccc}
\hline Treatments & $\begin{array}{c}\mathrm{N}_{2} \mathrm{O} \\
\text { Emission }\end{array}$ & $\mathrm{DOC}$ & $\mathrm{NH}_{4}{ }^{+}$ & $\mathrm{NO}_{3}{ }^{-}$ & $\begin{array}{c}\mathrm{AOA} \\
\text { amo } A\end{array}$ & $\begin{array}{c}\mathrm{AOB} \\
\text { amoA }\end{array}$ & nirK & nirS & nosZ \\
\hline $\mathrm{C}$ & $* * *$ & $* *$ & $*$ & $* * *$ & $*$ & $*$ & $* * *$ & $* * *$ & $* *$ \\
$\mathrm{~N}$ & $* * *$ & $\mathrm{~ns}$ & $* *$ & $* *$ & $* *$ & $* * *$ & $\mathrm{~ns}$ & $* * *$ & $* * *$ \\
$\mathrm{C} \times \mathrm{N}$ & ${ }^{* * *}$ & $* *$ & $* * *$ & $* * *$ & $*$ & $\mathrm{~ns}$ & $\mathrm{~ns}$ & $*$ & $* *$ \\
${ }^{*} p<0.05,{ }^{* *} p<0.01,^{* * *} p<0.001$. & & & & & & & &
\end{tabular}

\subsection{Soil DOC, Mineral N Content and Functional Genes Related to $\mathrm{N}_{2} \mathrm{O}$}

In the $\mathrm{CT}, \mathrm{C}$, and $\mathrm{N}$ treatments, $\mathrm{ZnO}$ NPs did not significantly $(p<0.01)$ affect the DOC content, there were no significant trends in the $\mathrm{NH}_{4}{ }^{+}$content with increasing $\mathrm{ZnO}$ NPs concentration, and the $\mathrm{NO}_{3}{ }^{-}$content significantly $(p<0.01)$ decreased with increasing $\mathrm{ZnO}$ NPs concentration (Tables 2 and 3 ). After both $\mathrm{C}$ and $\mathrm{N}$ addition, $\mathrm{ZnO}$ NPs significantly $(p<0.01)$ affected these variables, as DOC and $\mathrm{NO}_{3}{ }^{-}$contents decreased but $\mathrm{NH}_{4}{ }^{+}$ increased with increasing ZnO NPs concentrations (Tables 2 and 3).

Table 2. Soil DOC, $\mathrm{NH}_{4}{ }^{+}$, and $\mathrm{NO}_{3}{ }^{-}$contents at different $\mathrm{ZnO}$ NPs concentrations $(0,100,500$, and $1000 \mathrm{mg} \mathrm{kg}^{-1}$ ) in the treatments with no addition, $\mathrm{C}$ addition alone, $\mathrm{N}$ addition alone, and both $\mathrm{C}$ and $\mathrm{N}$ addition. Different letters indicate statistically significant differences (LSD, 5\%).

\begin{tabular}{|c|c|c|c|c|}
\hline Substrates & ZnO NPs Levels & DOC (mg C kg-1) & $\mathrm{NH}_{4}{ }^{+}\left(\mathrm{mg} \mathrm{N} \mathrm{kg}^{-1}\right)$ & $\mathrm{NO}_{3}{ }^{-}\left(\mathrm{mg} \mathrm{N} \mathrm{kg}^{-1}\right)$ \\
\hline \multirow{4}{*}{ No addition } & $0 \mathrm{mg} \mathrm{kg}^{-1}$ & $34.13 \pm 5.54 \mathrm{a}$ & $1.43 \pm 0.08 \mathrm{ab}$ & $61.30 \pm 1.56 \mathrm{a}$ \\
\hline & $100 \mathrm{mg} \mathrm{kg}^{-1}$ & $41.65 \pm 1.26 \mathrm{a}$ & $1.15 \pm 0.12 b c$ & $43.22 \pm 0.35 b$ \\
\hline & $500 \mathrm{mg} \mathrm{kg}^{-1}$ & $31.33 \pm 2.38 \mathrm{a}$ & $1.03 \pm 0.10 c$ & $44.45 \pm 0.64 b$ \\
\hline & $1000 \mathrm{mg} \mathrm{kg}^{-1}$ & $34.08 \pm 5.97 \mathrm{a}$ & $1.55 \pm 0.06 \mathrm{a}$ & $37.43 \pm 0.27 c$ \\
\hline
\end{tabular}


Table 2. Cont.

\begin{tabular}{|c|c|c|c|c|}
\hline Substrates & ZnO NPs Levels & $\mathrm{DOC}\left(\mathrm{mg} \mathrm{C} \mathrm{kg}{ }^{-1}\right)$ & $\mathrm{NH}_{4}{ }^{+}\left(\mathrm{mg} \mathrm{N} \mathrm{kg}{ }^{-1}\right)$ & $\mathrm{NO}_{3}{ }^{-}\left(\mathrm{mg} \mathrm{N} \mathrm{kg}{ }^{-1}\right)$ \\
\hline \multirow{4}{*}{$\mathrm{C}$ addition } & $0 \mathrm{mg} \mathrm{kg}^{-1}$ & $45.68 \pm 2.49 \mathrm{a}$ & $1.57 \pm 0.05 \mathrm{~b}$ & $31.03 \pm 1.13 \mathrm{a}$ \\
\hline & $100 \mathrm{mg} \mathrm{kg}^{-1}$ & $40.72 \pm 1.46 \mathrm{a}$ & $1.23 \pm 0.11 b$ & $15.98 \pm 0.05 c$ \\
\hline & $500 \mathrm{mg} \mathrm{kg}^{-1}$ & $45.30 \pm 10.26 \mathrm{a}$ & $1.22 \pm 0.16 \mathrm{~b}$ & $16.95 \pm 0.25 c$ \\
\hline & $1000 \mathrm{mg} \mathrm{kg}^{-1}$ & $40.88 \pm 5.15 \mathrm{a}$ & $2.23 \pm 0.03 \mathrm{a}$ & $19.70 \pm 0.26 \mathrm{~b}$ \\
\hline \multirow{4}{*}{$\mathrm{N}$ addition } & $0 \mathrm{mg} \mathrm{kg}^{-1}$ & $33.97 \pm 1.96 \mathrm{a}$ & $24.78 \pm 1.58 \mathrm{ab}$ & $69.57 \pm 0.38 \mathrm{a}$ \\
\hline & $100 \mathrm{mg} \mathrm{kg}^{-1}$ & $35.85 \pm 1.76 \mathrm{a}$ & $17.18 \pm 1.32 \mathrm{c}$ & $65.52 \pm 1.03 \mathrm{ab}$ \\
\hline & $500 \mathrm{mg} \mathrm{kg}^{-1}$ & $26.43 \pm 3.80 \mathrm{a}$ & $22.73 \pm 1.38 \mathrm{bc}$ & $58.55 \pm 3.29 \mathrm{~b}$ \\
\hline & $1000 \mathrm{mg} \mathrm{kg}^{-1}$ & $36.02 \pm 3.64 \mathrm{a}$ & $30.03 \pm 1.95 \mathrm{a}$ & $49.43 \pm 0.62 c$ \\
\hline \multirow{4}{*}{$\begin{array}{l}\mathrm{C} \text { and } \mathrm{N} \\
\text { addition }\end{array}$} & $0 \mathrm{mg} \mathrm{kg}^{-1}$ & $41.42 \pm 3.51 \mathrm{a}$ & $2.80 \pm 0.12 b c$ & $64.45 \pm 0.09 \mathrm{a}$ \\
\hline & $100 \mathrm{mg} \mathrm{kg}^{-1}$ & $31.18 \pm 3.63 \mathrm{a}$ & $1.53 \pm 0.08 c$ & $57.08 \pm 0.31 b$ \\
\hline & $500 \mathrm{mg} \mathrm{kg}^{-1}$ & $17.88 \pm 2.83 b$ & $3.97 \pm 0.24 b$ & $47.22 \pm 0.54 c$ \\
\hline & $1000 \mathrm{mg} \mathrm{kg}^{-1}$ & $12.87 \pm 1.92 \mathrm{~b}$ & $15.10 \pm 1.11 \mathrm{a}$ & $43.62 \pm 0.64 \mathrm{~d}$ \\
\hline
\end{tabular}

Table 3. Effect of $\mathrm{ZnO}$ NPs on soil DOC, $\mathrm{NH}_{4}{ }^{+}$, and $\mathrm{NO}_{3}{ }^{-}$contents and functional genes (AOA and $\mathrm{AOB}$ amoA, nirK, nirs and nosZ) related to $\mathrm{N}_{2} \mathrm{O}$ amendment with different substrates.

\begin{tabular}{|c|c|c|c|c|c|c|c|c|}
\hline Treatments & DOC & $\mathrm{NH}_{4}{ }^{+}$ & $\mathrm{NO}_{3}{ }^{-}$ & $\begin{array}{c}\text { AOA } \\
\text { amoA }\end{array}$ & $\begin{array}{c}\text { АOB } \\
\text { amoA }\end{array}$ & nirK & nirs & nosZ \\
\hline No addition & Ns & * & $* * *$ & * & ** & ns & * & Ns \\
\hline $\mathrm{C}$ addition & Ns & ** & $* *$ & $* *$ & ns & ns & ns & Ns \\
\hline $\mathrm{N}$ addition & Ns & * & $* * *$ & ns & ns & ns & * & Ns \\
\hline C AND $\mathrm{N}$ addition & $* *$ & $* * *$ & $* * *$ & $* * *$ & $* * *$ & ns & $* *$ & $* * *$ \\
\hline
\end{tabular}

Across all treatments, the functional gene copies related to $\mathrm{N}_{2} \mathrm{O}$ followed the order: nirs (from $2.53 \times 10^{6}$ to $1.51 \times 10^{7}$ ) > AOA amoA (from $2.02 \times 10^{5}$ to $1.46 \times 10^{6}$ ) > AOB amo $A$, nirK and nosZ $\left(\times 10^{4}\right)$ (Figure 3). Increasing $\mathrm{ZnO}$ NPs levels tended to decrease the abundance of AOA amoA (Figure $3 a$ ) but increase AOB amoA and nirS gene copies (Figure $3 \mathrm{~b}, \mathrm{~d}$ ). The nirK and nosZ genes were not significantly affected by ZnO NPs in the $\mathrm{CT}, \mathrm{C}$, and $\mathrm{N}$ treatments, but nos $\mathrm{Z}$ significantly increased with increasing ZnO NPs concentrations after amendment with both $\mathrm{C}$ and $\mathrm{N}$ substrates. In addition, in the presence of $\mathrm{ZnO} N \mathrm{Ns}, \mathrm{C}, \mathrm{N}$ and their interaction significantly influenced AOA amoA, nirS and nos $\mathrm{Z}$ gene copies (Table 1). The RDA results showed that the nirS and AOB amoA genes were negatively related to DOC on the first redundancy analysis axis, and $\mathrm{NH}_{4}{ }^{+}$and $\mathrm{NO}_{3}{ }^{-}$ were positively rel'ated to the AOA amo A gene but negatively associated with nos $\mathrm{Z}$ on the second redundancy analysis axis (Figure 4).

\subsection{Effect of $\mathrm{ZnO} \mathrm{NPs}$ on $\mathrm{N}_{2} \mathrm{O}$ Emission}

The RDA results showed that the nirS and $\mathrm{AOB}$ amoA genes were positively correlated with cumulative $\mathrm{N}_{2} \mathrm{O}$ emissions on the first redundancy analysis axis (Figure 4). PLS$\mathrm{PM}$ showed that changes in soil $\mathrm{NO}_{3}{ }^{-}$content, nitrifiers (AOB amoA) and denitrifiers (nirS) induced by $\mathrm{ZnO}$ NPs addition significantly affected $\mathrm{N}_{2} \mathrm{O}$ emissions (Figure 5a). Both nitrifiers (0.35) and denitrifiers (0.69) had significant positive direct effects on $\mathrm{N}_{2} \mathrm{O}$ emissions, while $\mathrm{NO}_{3}{ }^{-}$had both positive direct $(0.35)$ and negative indirect $(-0.15)$ effects on $\mathrm{N}_{2} \mathrm{O}$ emissions, resulting in a total effect of $\mathrm{NO}_{3}{ }^{-}$on $\mathrm{N}_{2} \mathrm{O}$ emissions of 0.20 (Figure $5 b$ ). 

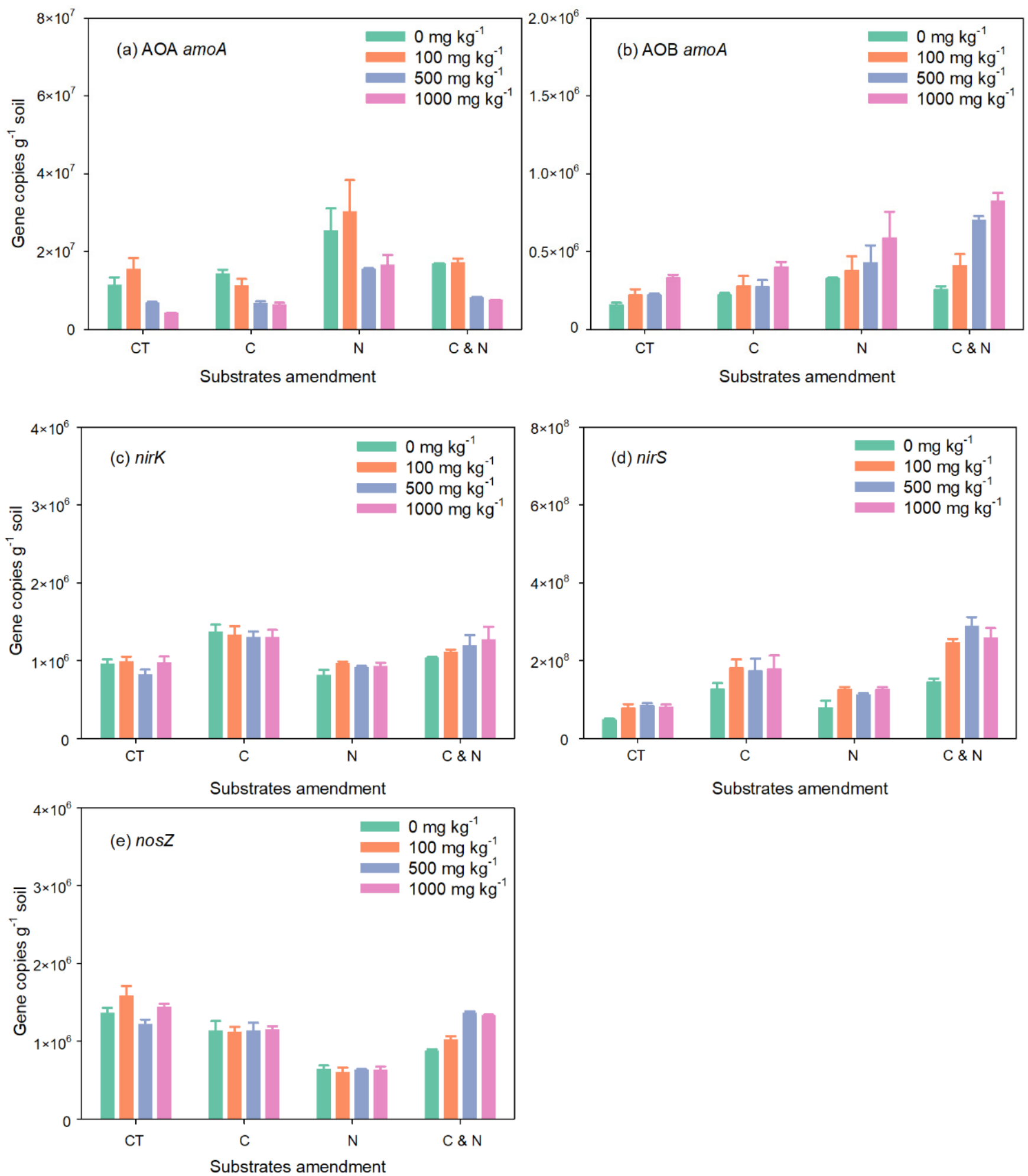

Substrates amendment

Figure 3. AOA amoA (a), AOB amoA (b), nirK (c), nirS (d) and nosZ (e) genes under no addition, $\mathrm{C}$ addition, $\mathrm{N}$ addition, and $\mathrm{C}$ and $\mathrm{N}$ addition at different $\mathrm{ZnO}$ NPs concentrations $\left(0,100,500\right.$ and $\left.1000 \mathrm{mg} \mathrm{kg}^{-1}\right)$. Error bars represent the standard error of the mean $(n=3)$. 


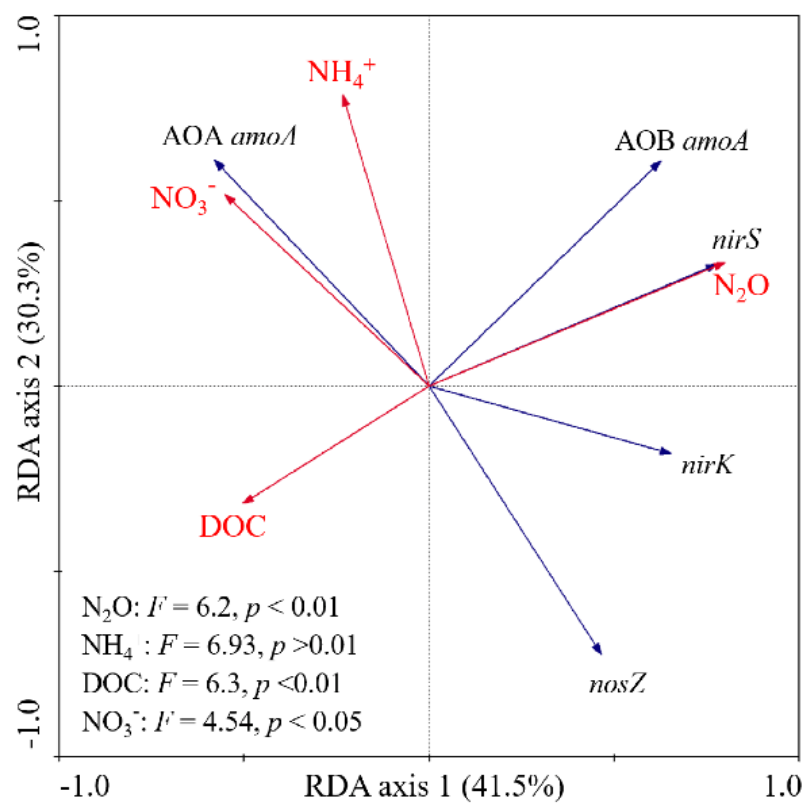

Figure 4. RDA ordination diagram of the relationships between cumulative $\mathrm{N}_{2} \mathrm{O}$ emissions and soil chemical variables (DOC, $\mathrm{NH}_{4}{ }^{+}$, and $\mathrm{NO}_{3}{ }^{-}$) with functional genes related to $\mathrm{N}_{2} \mathrm{O}(\mathrm{AOA}$ amoA, $\mathrm{AOB}$ amoA, nirK, nirS, and nosZ).

(a)

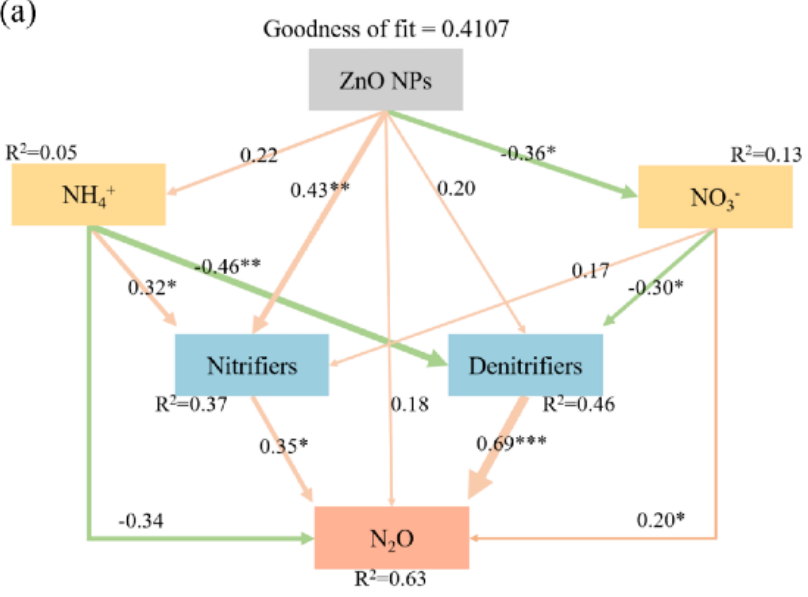

(b)

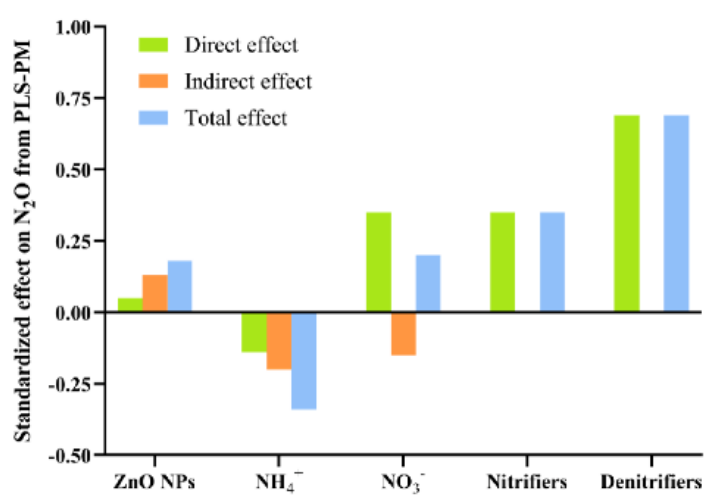

Figure 5. Direct and indirect effects of ZnO NPs on $\mathrm{N}_{2} \mathrm{O}$ emissions in PLS-PM. The left figure (a) describes the relationships among $\mathrm{ZnO} N P s$, soil $\mathrm{NH}_{4}{ }^{+}, \mathrm{NO}_{3}{ }^{-}$, nitrifiers and denitrifiers with respect to $\mathrm{N}_{2} \mathrm{O}$ emissions. Wider arrows indicate higher path coefficients, and orange and green colors indicate positive and negative effects, respectively. ${ }^{*},{ }^{* *}$ and ${ }^{* * *}$ indicate significance at $p<0.05, p<0.01$, and $p<0.001$, respectively. The right figure $(\mathbf{b})$ describes the standardized direct, indirect and total effects derived from the PLS-PM.

\section{Discussion}

In the present study, $\mathrm{ZnO}$ NPs affected $\mathrm{N}_{2} \mathrm{O}$ emissions by controlling nitrification and denitrification pathways. Increasing $\mathrm{ZnO}$ NPs levels decreased the amo $A$ gene copy number of AOA, which probably reduced the production of $\mathrm{N}_{2} \mathrm{O}$ through nitrification. However, this nanomaterial increased the abundances of $\mathrm{AOB}$ amo $A$ and nirS, which induced more $\mathrm{N}_{2} \mathrm{O}$ production in the soils. This result disagreed with Phan et al. [29], who found that the presence of $\mathrm{ZnO}$ NPs reduced the gene expression levels of AOB amoA and nirK in a wastewater system. Cumulative $\mathrm{N}_{2} \mathrm{O}$ emissions were closely correlated with the nirS gene, and the $\mathrm{NO}_{3}{ }^{-}$content also decreased with increasing $\mathrm{ZnO}$ NPs concentration, 
indicating that $\mathrm{ZnO}$ NPs affect $\mathrm{N}_{2} \mathrm{O}$ emissions probably by enhancing nitrite reduction in the denitrification process. However, Durenkamp et al. [19] observed that ZnO NPs did not significantly affect $\mathrm{N}_{2} \mathrm{O}$ emissions from soil/sewage sludge mixtures. In a biological nitrogen removal system, Ye et al. [17] showed that the presence of ZnO NPs inhibited $\mathrm{N}_{2} \mathrm{O}$ production by largely reducing the functional genes related to nitrite or nitrate reduction rather than the reduction of $\mathrm{N}_{2} \mathrm{O}$. These different results are probably due to the impact of $\mathrm{ZnO} N P s$ on nitrifiers and denitrifiers related to $\mathrm{N}_{2} \mathrm{O}$ depending on different environmental conditions. In the soil environment, $\mathrm{N}_{2} \mathrm{O}$ is produced through both nitrification and denitrification [23], whereas in other conditions (such as biological nitrogen removal systems), denitrification is the major pathway for $\mathrm{N}_{2} \mathrm{O}$ production $[17,18]$.

The impact of NPs on $\mathrm{N}_{2} \mathrm{O}$ emissions also depends on their types in the soil environment [8-11,19,30-33]. Zhao et al. [8] observed that CuO NPs (ranging from 10-500 $\mathrm{mg} \mathrm{kg}^{-1}$ ) continuously reduced soil $\mathrm{N}_{2} \mathrm{O}$ emissions. Low-dose silver (Ag) NPs unaffected or stimulated $\mathrm{N}_{2} \mathrm{O}$ production, but a high dose of this material would inhibit $\mathrm{N}_{2} \mathrm{O}$ emission due to toxicity [30-33]. Our results disagree with these studies, and we observed that 100 and $500 \mathrm{mg} \mathrm{kg}^{-1} \mathrm{ZnO}$ NPs did not affect $\mathrm{N}_{2} \mathrm{O}$ production, but $1000 \mathrm{mg} \mathrm{kg}^{-1} \mathrm{ZnO}$ NPs stimulated $\mathrm{N}_{2} \mathrm{O}$ production in the treatment without $\mathrm{C}$ and $\mathrm{N}$ amendments. This result was consistent with Avila-Arias et al. [10], who found that high-dose $\mathrm{Li}_{2} \mathrm{O}$ NPs (1000 mg kg ${ }^{-1}$ ) increased soil $\mathrm{N}_{2} \mathrm{O}$ emissions, and Wu et al. [9] found that the application of sludge with $\mathrm{Ag}_{2} \mathrm{~S}$ NPs to soil significantly enhanced the release of $\mathrm{N}_{2} \mathrm{O}$ from soils. However, Durenkamp et al. [19] showed that the addition of sewage sludge into soil enriched with both $\mathrm{ZnO}$ and $\mathrm{Ag}$ NPs did not affect $\mathrm{N}_{2} \mathrm{O}$ emissions. Yang et al. [11] also observed no significant effect of $\mathrm{Fe}_{2} \mathrm{O}_{3}$ NPs $\left(0.5-500 \mathrm{mg} \mathrm{kg}^{-1}\right)$ on $\mathrm{N}_{2} \mathrm{O}$ emissions in paddy soils.

The inconsistent effect of these NPs on $\mathrm{N}_{2} \mathrm{O}$ emissions is probably due to the different responses of soil nitrification and denitrification processes to nanomaterials. Zhao et al. [8] found that the negative effect of $\mathrm{CuO} N P s$ on $\mathrm{N}_{2} \mathrm{O}$ emissions was mainly due to this nanoparticle inhibiting the ability of denitrification to accept electrons and then reducing the reductase activities of both nitrate and nitric oxide. Ag NPs decreased soil $\mathrm{N}_{2} \mathrm{O}$ production, probably by inhibiting urease activity [34] or functional genes related to nitrification [35-37] and denitrification [38]. However, $\mathrm{Ag}_{2} \mathrm{~S}$ NPs could improve functional gene-encoded nitrification and denitrification and then increase $\mathrm{N}_{2} \mathrm{O}$ emissions in saline soil [9]. In addition, Yang et al. [11] found that $\mathrm{Fe}_{2} \mathrm{O}_{3} \mathrm{NPs}$ did not significantly change the abundances of functional genes related to $\mathrm{N}_{2} \mathrm{O}$ production and reduction.

As expected, the amendment of the $C$ substrate significantly stimulated the production of $\mathrm{N}_{2} \mathrm{O}$ in the presence of $\mathrm{ZnO}$ NPs due to the following: (1) ZnO NPs inhibited the key enzymes of glucose degradation and then reduced the electrons and energy for denitrifiers [16]. However, the addition of glucose probably partly compensates for the negative effect of $\mathrm{ZnO} N P s$ on the power available for denitrifiers and then stimulates $\mathrm{N}_{2} \mathrm{O}$ production in denitrification. (2) The effect of $\mathrm{ZnO}$ NPs on $\mathrm{N}_{2} \mathrm{O}$ produced via denitrification pathways relies on $\mathrm{O}_{2}$ availability, whereas the addition of a $\mathrm{C}$ substrate consumes $\mathrm{O}_{2}$ in the soil through heterotrophic respiration and then temporarily creates an anaerobic environment for denitrification to produce $\mathrm{N}_{2} \mathrm{O}[23-25,39]$. Indeed, in the present study, the amendment of $\mathrm{C}$ substrate increased the abundance of nirK, which probably stimulated $\mathrm{N}_{2} \mathrm{O}$ production through enhanced nitrite reduction.

Our results indicated that in fields polluted by ZnO NPs, some management practices, such as the application of organic manure or crop residue that supply labile $\mathrm{C}$ and $\mathrm{N}$ substrates probably cause a high risk of $\mathrm{N}_{2} \mathrm{O}$ emissions and then contribute to global climate warming. However, two limitations should be noted in this experiment. First, $\mathrm{ZnO}$ NPs could dissolve in the soil environment and be consumed by microorganisms [14], which probably resulted in the positive effect of $\mathrm{ZnO} N P s$ on $\mathrm{N}_{2} \mathrm{O}$ emissions. Indeed, Wu et al. [40] observed a rapid dissolution of $\mathrm{ZnO}$ NPs in neutral soil and solubilized them in $\mathrm{Zn}^{2+}$. Further study should be conducted to analyze $\mathrm{Zn}^{2+}$ originating from $\mathrm{ZnO}$ NPs in the soil and separate the contribution of $\mathrm{ZnO} N P s$ and $\mathrm{Zn}^{2+}$ to $\mathrm{N}_{2} \mathrm{O}$ production and reduction. Second, $\mathrm{Zn}^{2+}$ dissolved in the soil could be taken up by plants as a micronutrient, 
which could increase the nitrogen use efficiency and then indirectly reduce the substrate for nitrification and denitrification processes [4]. In addition, the use of NPs is a useful method to support plant growth [2], which could indirectly affect nitrification and denitrification processes by regulating the $\mathrm{N}$ substrate. Future studies will need to determine the impact of $\mathrm{ZnO}$ NPs on $\mathrm{N}_{2} \mathrm{O}$ production in the presence of crops.

\section{Conclusions}

Our findings showed that $\mathrm{ZnO} N P s$ accelerated the release of $\mathrm{N}_{2} \mathrm{O}$ from soils after $\mathrm{C}$ or $\mathrm{N}$ substrate amendment. The interaction of $\mathrm{C}$ and $\mathrm{N}$ caused the total $\mathrm{N}_{2} \mathrm{O}$ emissions to substantially increase by 6.28-8.35 times compared with the control treatment without $\mathrm{ZnO}$ NPs. Moreover, this stimulatory effect was greater for soils with low $\mathrm{ZnO}$ NPs concentrations (100 mg kg-1) than for soils with 500 and $1000 \mathrm{mg} \mathrm{kg}^{-1} \mathrm{ZnO} \mathrm{NPs}$. Although $\mathrm{ZnO}$ NPs reduced the $\mathrm{N}_{2} \mathrm{O}$ production rate by decreasing the abundances of AOA amo $A$ functional genes, the increase in total $\mathrm{N}_{2} \mathrm{O}$ emissions was mainly attributed to $\mathrm{ZnO}$ NPs increasing the abundances of functional genes related to AOB and nitrite reductase. This result indicated that $\mathrm{ZnO} N$ Ps probably induced greater $\mathrm{N}_{2} \mathrm{O}$ production than $\mathrm{N}_{2} \mathrm{O}$ reduction and thus stimulated the release of $\mathrm{N}_{2} \mathrm{O}$ from soils. Overall, our results demonstrate that the amendment of available $\mathrm{C}$ and $\mathrm{N}$ substrates probably results in a high risk of $\mathrm{N}_{2} \mathrm{O}$ emissions from soils in the presence of $\mathrm{ZnO}$ NPs, contributing to global warming and ozone depletion.

Supplementary Materials: The following are available online at https: / www.mdpi.com/article / 10.3390 /agriculture11080730/s1, Figure S1: The change in $\mathrm{N}_{2} \mathrm{O}$ concentration after all bottles were opened and placed in a fuming cupboard for 5 minutes. The $\mathrm{N}_{2} \mathrm{O}$ concentration at 1 min indicated the initial concentration, Table S1: Primers and the thermal cycling conditions of functional genes related to $\mathrm{N}_{2} \mathrm{O}$.

Author Contributions: Conceptualization, Z.F., Y.Y., H.Y. and C.G.; methodology, Z.F., Y.Y., H.Y. and C.G.; software, Z.F., Y.Y., H.Y. and C.G.; validation, Z.F., Y.Y., H.Y. and C.G.; formal analysis, Z.F., Y.Y., H.Y. and C.G.; investigation, Z.F., Y.Y., H.Y. and C.G.; data curation, Z.F. and Y.Y.; writing-original draft preparation, Z.F.; writing-review and editing, Z.F. and Y.Y.; supervision, H.Y. and C.G. All authors have read and agreed to the published version of the manuscript.

Funding: This work was funded by the National Key R \& D Program of China (2020YFC1806900) and the National Natural Science Foundation of China (41807040, 42077036, 42021005).

Institutional Review Board Statement: Not applicable.

Informed Consent Statement: Not applicable.

Data Availability Statement: The data presented in this study are available in the article.

Conflicts of Interest: The authors declare no conflict of interest.

\section{References}

1. Lewis, R.W.; Bertsch, P.M.; McNear, D.H. Nanotoxicity of engineered nanomaterials (ENMs) to environmentally relevant beneficial soil bacteria-A critical review. Nanotoxicology 2019, 13, 392-428. [CrossRef]

2. Rajput, V.D.; Minkina, T.; Kumari, A.; Harish; Singh, V.K.; Verma, K.K.; Mandzhieva, S.; Sushkova, S.; Srivastava, S.; Keswani, C. Coping with the challenges of abiotic stress in plants: New dimensions in the field application of nanoparticles. Plants 2021, 10, 1221. [CrossRef] [PubMed]

3. Ma, H.; Williams, P.L.; Diamond, S.A. Ecotoxicity of manufactured ZnO nanoparticles-A review. Environ. Pollut. 2013, 172, 76-85. [CrossRef]

4. $\quad$ Rajput, V.D.; Minkina, T.M.; Behal, A.; Sushkova, S.N.; Mandzhieva, S.; Singh, R.; Gorovtsov, A.; Tsitsuashvili, V.S.; Purvis, W.O.; Ghazaryan, K.A.; et al. Effects of zinc-oxide nanoparticles on soil, plants, animals and soil organisms: A review. Environ. Nanotechnol. Monit. Manag. 2018, 9, 76-84. [CrossRef]

5. Luo, Z.; Qiu, Z.; Chen, Z.; Du Laing, G.; Liu, A.; Yan, C. Impact of $\mathrm{TiO}_{2}$ and $\mathrm{ZnO}$ nanoparticles at predicted environmentally relevant concentrations on ammonia-oxidizing bacteria cultures under ammonia oxidation. Environ. Sci. Pollut. Res. 2015, 22, 2891-2899. [CrossRef] [PubMed] 
6. Parada, J.; Rubilar, O.; Sousa, D.Z.; Martinez, M.; Fernandez-Baldo, M.A.; Tortella, G.R. Short term changes in the abundance of nitrifying microorganisms in a soil-plant system simultaneously exposed to copper nanoparticles and atrazine. Sci. Total. Environ. 2019, 670, 1068-1074. [CrossRef]

7. Simonin, M.; Cantarel, A.A.M.; Crouzet, A.; Gervaix, J.; Martins, J.M.F.; Richaume, A. Negative effects of copper oxide nanoparticles on carbon and nitrogen cycle microbial activities in contrasting agricultural soils and in presence of plants. Front. Microbiol. 2018, 9, 3102. [CrossRef]

8. Zhao, S.; Su, X.; Wang, Y.; Yang, X.; Bi, M.; He, Q.; Chen, Y. Copper oxide nanoparticles inhibited denitrifying enzymes and electron transport system activities to influence soil denitrification and $\mathrm{N}_{2} \mathrm{O}$ emission. Chemosphere 2020, 245, 125394. [CrossRef]

9. Wu, J.; Bai, Y.; Lu, B.; Li, C.; Menzies, N.W.; Bertsch, P.M.; Wang, Z.; Wang, P.; Kopittke, P.M. Application of sewage sludge containing environmentally-relevant silver sulfide nanoparticles increases emissions of nitrous oxide in saline soils. Environ. Pollut. 2020, 265, 114807. [CrossRef]

10. Avila-Arias, H.; Nies, L.F.; Gray, M.B.; Turco, R.F. Impacts of molybdenum-, nickel-, and lithium- oxide nanomaterials on soil activity and microbial community structure. Sci. Total Environ. 2019, 652, 202-211. [CrossRef] [PubMed]

11. Yang, H.; Zhang, X.; Dang, D.; Zheng, L.; Yang, Q.; Yu, Y. Effects of iron oxide nanoparticles on $\mathrm{CH}_{4}$ and $\mathrm{N}_{2} \mathrm{O}$ emissions and microbial communities in two typical paddy soils. Chin. J. Appl. Environ. Biol. 2021, 7, 725-733. [CrossRef]

12. Ge, Y.; Schimel, J.P.; Holden, P.A. Evidence for negative effects of $\mathrm{TiO}_{2}$ and $\mathrm{ZnO}$ nanoparticles on soil bacterial communities. Environ. Sci. Technol. 2011, 45, 1659-1964. [CrossRef] [PubMed]

13. Chai, H.; Yao, J.; Sun, J.; Zhang, C.; Liu, W.; Zhu, M.; Ceccanti, B. The effect of metal oxide nanoparticles on functional bacteria and metabolic profiles in agricultural soil. Bull. Environ. Contam. Toxicol. 2015, 94, 490-495. [CrossRef] [PubMed]

14. Rashid, M.I.; Shahzad, T.; Shahid, M.; Ismail, I.M.; Shah, G.M.; Almeelbi, T. Zinc oxide nanoparticles affect carbon and nitrogen mineralization of Phoenix dactylifera leaf litter in a sandy soil. J. Hazard. Mater. 2017, 324, 298-305. [CrossRef]

15. Du, W.; Sun, Y.; Ji, R.; Zhu, J.; Wu, J.; Guo, H. $\mathrm{TiO}_{2}$ and $\mathrm{ZnO}$ nanoparticles negatively affect wheat growth and soil enzyme activities in agricultural soil. J. Environ. Monit. 2011, 13, 822-828. [CrossRef]

16. Zheng, X.; Su, Y.; Chen, Y.; Wan, R.; Liu, K.; Li, M.; Yin, D. Zinc oxide nanoparticles cause inhibition of microbial denitrification by affecting transcriptional regulation and enzyme activity. Environ. Sci. Technol. 2014, 48, 13800-13807. [CrossRef]

17. Ye, J.; Gao, H.; Domingo-Felez, C.; Wu, J.; Zhan, M.; Yu, R.; Smets, B.F. Insights into chronic zinc oxide nanoparticle stress responses of biological nitrogen removal system with nitrous oxide emission and its recovery potential. Bioresour. Technol. 2021, 327, 124797. [CrossRef]

18. Ye, J.; Gao, H.; Wu, J.; Chang, Y.; Chen, Z.; Yu, R. Responses of nitrogen transformation processes and $\mathrm{N}_{2} \mathrm{O}$ emissions in biological nitrogen removal system to short-term ZnO nanoparticle stress. Sci. Total. Environ. 2020, 705, 135916. [CrossRef]

19. Durenkamp, M.; Pawlett, M.; Ritz, K.; Harris, J.A.; Neal, A.L.; McGrath, S.P. Nanoparticles within WWTP sludges have minimal impact on leachate quality and soil microbial community structure and function. Environ. Pollut. 2016, 211, 399-405. [CrossRef]

20. Yu, Y.; Zhao, C.; Zheng, N.; Jia, H.; Yao, H. Interactive effects of soil texture and salinity on nitrous oxide emissions following crop residue amendment. Geoderma 2019, 337, 1146-1154. [CrossRef]

21. Muhammad, W.; Vaughan, S.M.; Dalal, R.C.; Menzies, N.W. Crop residues and fertilizer nitrogen influence residue decomposition and nitrous oxide emission from a Vertisol. Biol. Fertil. Soils 2010, 47, 15-23. [CrossRef]

22. Chen, H.; Li, X.; Hu, F.; Shi, W. Soil nitrous oxide emissions following crop residue addition: A meta-analysis. Glob. Chang. Biol. 2013, 19, 2956-2964. [CrossRef]

23. Daly, E.J.; Hernandez-Ramirez, G. Sources and priming of soil $\mathrm{N}_{2} \mathrm{O}$ and $\mathrm{CO}_{2}$ production: Nitrogen and simulated exudate additions. Soil Biol. Biochem. 2020, 149, 107942. [CrossRef]

24. Morley, N.; Baggs, E.M. Carbon and oxygen controls on $\mathrm{N}_{2} \mathrm{O}$ and $\mathrm{N}_{2}$ production during nitrate reduction. Soil Biol. Biochem. 2010, 42, 1864-1871. [CrossRef]

25. Liang, L.L.; Grantz, D.A.; Jenerette, G.D. Multivariate regulation of soil $\mathrm{CO}_{2}$ and $\mathrm{N}_{2} \mathrm{O}$ pulse emissions from agricultural soils. Glob. Chang. Biol. 2016, 22, 1286-1298. [CrossRef]

26. Ouyang, Y.; Evans, S.E.; Friesen, M.L.; Tiemann, L.K. Effect of nitrogen fertilization on the abundance of nitrogen cycling genes in agricultural soils: A meta-analysis of field studies. Soil Biol. Biochem. 2018, 127, 71-78. [CrossRef]

27. Waalewijn-Kool, P.L.; Diez Ortiz, M.; van Gestel, C.A. Effect of different spiking procedures on the distribution and toxicity of $\mathrm{ZnO}$ nanoparticles in soil. Ecotoxicology 2012, 21, 1797-1804. [CrossRef]

28. Tian, Q.; Yang, X.; Wang, X.; Liao, C.; Li, Q.; Wang, M.; Wu, Y.; Liu, F. Microbial community mediated response of organic carbon mineralization to labile carbon and nitrogen addition in topsoil and subsoil. Biogeochemistry 2016, 128, 125-139. [CrossRef]

29. Phan, D.C.; Pasha, A.B.M.T.; Carwile, N.; Kapoor, V. Effect of zinc oxide nanoparticles on physiological activities and gene expression of wastewater nitrifying bacteria. Environ. Eng. Sci. 2020, 37, 328-336. [CrossRef]

30. Li, Y.; Zhao, R.; Wang, L.; Niu, L.; Wang, C.; Hu, J.; Wu, H.; Zhang, W.; Wang, P. Silver nanoparticles and Fe(III) co-regulate microbial community and $\mathrm{N}_{2} \mathrm{O}$ emission in river sediments. Sci. Total. Environ. 2020, 706, 135712. [CrossRef]

31. Zheng, Y.; Hou, L.; Liu, M.; Newell, S.E.; Yin, G.; Yu, C.; Zhang, H.; Li, X.; Gao, D.; Gao, J.; et al. Effects of silver nanoparticles on nitrification and associated nitrous oxide production in aquatic environments. Sci. Adv. 2017, 3, e1603229. [CrossRef]

32. Beddow, J.; Stolpe, B.; Cole, P.A.; Lead, J.R.; Sapp, M.; Lyons, B.P.; Colbeck, I.; Whitby, C. Nanosilver inhibits nitrification and reduces ammonia-oxidising bacterial but not archaeal amoA gene abundance in estuarine sediments. Environ. Microbiol. 2017, 19, 500-510. [CrossRef] 
33. Samarajeewa, A.D.; Velicogna, J.R.; Princz, J.I.; Subasinghe, R.M.; Scroggins, R.P.; Beaudette, L.A. Effect of silver nano-particles on soil microbial growth, activity and community diversity in a sandy loam soil. Environ. Pollut. 2017, 220, 504-513. [CrossRef]

34. McGee, C.F.; Storey, S.; Clipson, N.; Doyle, E. Concentration-dependent responses of soil bacterial, fungal and nitrifying communities to silver nano and micron particles. Environ. Sci. Pollut. Res. 2018, 25, 18693-18704. [CrossRef]

35. Masrahi, A.; VandeVoort, A.R.; Arai, Y. Effects of silver nanoparticle on soil-nitrification processes. Arch. Environ. Contam. Toxicol. 2014, 66, 504-513. [CrossRef] [PubMed]

36. Yan, C.; Huang, J.; Cao, C.; Li, R.; Ma, Y.; Wang, Y. Effects of PVP-coated silver nanoparticles on enzyme activity, bacterial and archaeal community structure and function in a yellow-brown loam soil. Environ. Sci. Pollut. Res. 2020, 27, 8058-8070. [CrossRef]

37. Wang, J.; Shu, K.; Zhang, L.; Si, Y. Effects of silver nanoparticles on soil microbial communities and bacterial nitrification in suburban vegetable soils. Pedosphere 2017, 27, 482-490. [CrossRef]

38. Wu, L.; Zhu, G.; Zhang, X.; Si, Y. Silver nanoparticles inhibit denitrification by altering the viability and metabolic activity of Pseudomonas stutzeri. Sci. Total. Environ. 2020, 706, 135711. [CrossRef]

39. Cheng, Y.-F.; Zhang, Q.; Li, G.-F.; Xue, Y.; Zheng, X.-P.; Cai, S.; Zhang, Z.-Z.; Jin, R.-C. Long-term effects of copper nanoparticles on granule-based denitrification systems: Performance, microbial communities, functional genes and sludge properties. Bioresour. Technol. 2019, 289, 121707. [CrossRef] [PubMed]

40. Wu, P.; Cui, P.; Du, H.; Alves, M.E.; Zhou, D.; Wang, Y. Long-term dissolution and transformation of ZnO in soils: The roles of soil $\mathrm{pH}$ and $\mathrm{ZnO}$ particle size. J. Hazard. Mater. 2021, 415, 125604. [CrossRef] 